\title{
Asymmetric red-bluish foot due to acrodermatitis chronica atrophicans
}

\author{
Anh Ly Nguyen, ${ }^{1}$ Wim J A de Kort, ${ }^{1}$ Chantal C W Theunissen ${ }^{2}$
}

'Department of Dermatology, Amphia Ziekenhuis, Breda,

North Brabant,

The Netherlands

2Department of Dermatology, Medisch Centrum Leeuwarden, Leeuwarden, Fryslân,

The Netherlands

\section{Correspondence to} Dr Chantal Theunissen, theunissen@me.com

Accepted 6 June 2016
To cite: Nguyen AL, de Kort WJA, Theunissen CCW. BMJ Case Rep Published online: [please include Day Month Year] doi:10.1136/ bcr-2016-216033

\section{DESCRIPTION}

\section{Background}

Acrodermatitis chronica atrophicans (ACA) is the first presentation of Lyme borreliosis in about 3\% of patients. ${ }^{1}$ This case is important as it reminds physicians that ACA should be considered in the differential diagnosis of non-acute red-bluish discolouration of an extremity.

\section{Case presentation}

A 72-year-old woman presented with a 7-year history of progressive red-bluish discolouration and some numbness of her left foot, which had been undiagnosed for years. She experienced no pain, burning or itching sensation of the foot. There was no aggravation in hot or cold environments. Arthritis or Raynaud's disease were not present. The patient could not recall a trauma or tick bite. During the past years, she had also experienced extreme fatigue, abdominal and atypical thoracic pains. Internal and cardiological consultation revealed no diagnosis, and the symptoms disappeared spontaneously over the years. Owing to increasing concerns, she recently visited a vascular surgeon who ruled out chronic venous insufficiency and peripheral artery disease. Physical examination at our department revealed a red-bluish discolouration and minimal swelling of the left foot with thin papery dry translucent skin and clearly visible superficial veins (figures 1 and 2).

\section{Investigations}

Histology indicated epidermal atrophy with hyperkeratosis. The superficial dermis showed a perivascular infiltrate consisting of some lymphocytes but primarily plasma cells reaching into the deeper layer of the dermis. Stains for fungi and spirochaetes were negative. Borrelia DNA was not detected in lesional skin tissue using the PCR. The

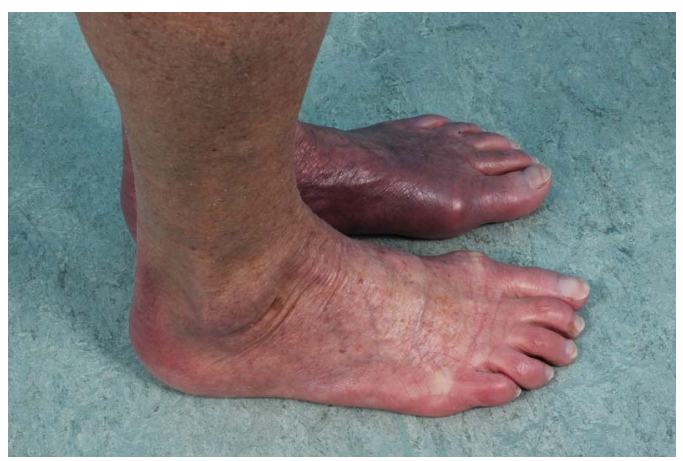

Figure 1 Asymmetric red-bluish discolouration of the left foot with thin papery dry translucent skin, taken from right side of the patient. enzyme-linked immunosorbant assay for Borrelia IgG and Western blot for Borrelia IgM and IgG were positive.

\section{Differential diagnosis}

The differential diagnosis based on clinical examination consisted of acrocyanosis, vasculitis and ACA. Based on the clinical, immunoserological, and histopathological examination, the patient was diagnosed with ACA.

\section{Treatment}

The patient was also referred to the neurologist, who diagnosed a sensoric polyneuropathy and ruled out neuroborreliosis. We treated the patient with doxycycline $200 \mathrm{mg}$ daily for two cycli of 4 weeks, due to persistent discolouration of her foot.

\section{Outcome}

Three months later the discolouration of the foot significantly decreased; however, the skin atrophy and polyneuropathy remained unchanged.

\section{DISCUSSION}

ACA is a rare manifestation of late Lyme disease and is often underdiagnosed. This may be due to several factors. Namely, ACA can occur up to 8 years after a bite by the tick-borne spirochete Borrelia burgdorferi. Also, 30\% of patients with ACA could not recall a tick bite and only $18 \%$ had a history of untreated erythema chronicum migrans prior to their symptoms. ${ }^{2}$ This makes it difficult to connect the dots, as ACA is not often considered in the differential diagnosis of a non-acute red-bluish discoloured extremity. Furthermore, the inflammatory phase of ACA can resemble conditions such as acrocyanosis, perniones, Raynaud's disease or chronic venous insufficiency. Also, $32 \%$ of patients with ACA were examined by five or more

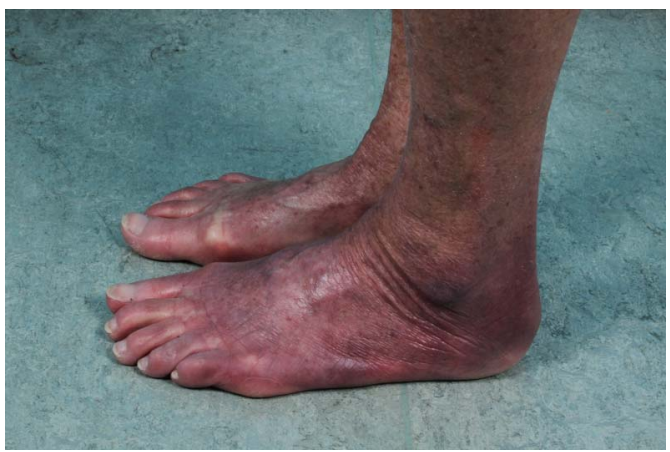

Figure 2 Asymmetric red-bluish discolouration of the left foot with thin papery dry translucent skin, taken from left side of the patient. 
physicians before the correct diagnosis was made. ${ }^{2}$ Thus, patients can be misdiagnosed or remain undiagnosed for years, which leads to a considerable delay in diagnosis and treatment. Complications due to delayed diagnosis can entail irreversible cutaneous damage such as skin atrophy or other late systemic complications such as arthritis, peripheral polyneuropathy, encephalomyelitis, and cardiomyopathy. ${ }^{3}$ In our case, it remains

\section{Learning points}

- Acrodermatitis chronica atrophicans should be considered in the differential diagnosis of non-acute asymmetric red-bluish discolouration of an extremity.

- Early recognition, diagnosis and treatment of acrodermatitis chronica atrophicans is crucial in order to prevent irreversible cutaneous damage and systemic complications of this disease.

- Early treatment also prevents uncertainties regarding the interpretation of non-specific symptoms in relation to Lyme disease. equivocal whether the polyneuropathy and transient systemic symptoms were related to the Lyme disease.

In $90-100 \%$ of patients with chronic Lyme disease, serology is positive for IgG antibodies against B. burgdorferi. IgM antibodies are often false positive in this late stage and thus not useful in diagnosing chronic Lyme. ${ }^{3}$ The sensitivity of the PCR in detecting Borrelia DNA in lesional skin tissue ranges from $56 \%$ to $100 \%$; its role in diagnosing ACA is, therefore, also limited. ${ }^{4}$

First-line management of chronic Lyme consists of treatment with doxycycline $200 \mathrm{mg}$ daily for 3-4 weeks. ${ }^{3}$

Competing interests None declared.

Patient consent Obtained.

Provenance and peer review Not commissioned; externally peer reviewed.

\section{REFERENCES}

1 Berglund J, Eitrem R, Ornstein K, et al. An epidemiologic study of Lyme disease in southern Sweden. N Engl J Med 1995;333:1319-24.

2 Åsbrink E, Hovmark A, Olsson I. Clinical manifestations of acrodermatitis chronica atrophicans in 50 Swedish patients. Zentralb/ Bakteriol Mikrobiol Hyg A 1986;263:253-61.

3 Ljøstad U, Mygland A. Chronic Lyme; diagnostic and therapeutic challenges. Acta Neurol Scand, Suppl 2013;196:38-47.

4 Aguero-Rosenfeld ME, Wang G, Schwartz I, et al. Diagnosis of Lyme borreliosis. Clin Microbiol Rev 2005;18:484-509.

Copyright 2016 BMJ Publishing Group. All rights reserved. For permission to reuse any of this content visit http://group.bmj.com/group/rights-licensing/permissions.

BMJ Case Report Fellows may re-use this article for personal use and teaching without any further permission.

Become a Fellow of BMJ Case Reports today and you can:

- Submit as many cases as you like

- Enjoy fast sympathetic peer review and rapid publication of accepted articles

- Access all the published articles

- Re-use any of the published material for personal use and teaching without further permission

For information on Institutional Fellowships contact consortiasales@bmjgroup.com

Visit casereports.bmj.com for more articles like this and to become a Fellow 